\title{
Intention to Use Cloud Accounting System Among SMEs in Malaysia: A Conceptual Framework of a Modified Unified Theory of Acceptance and Use of Technology (UTAUT) Model
}

\author{
Zul Karami Che Musa ${ }^{1}$, Mohd Nazri Muhayiddin ${ }^{1}$, Mohd Nor Hakimin Yusoff ${ }^{1}$, Mohammad Ismail ${ }^{1} \&$ Mahathir \\ Muhamad $^{1}$ \\ ${ }^{1}$ Universiti Malaysia Kelantan, Malaysia \\ Correspondence: Zul Karami Che Musa, Universiti Malaysia Kelantan, Malaysia.
}

Received: May 1, 2019

doi:10.5430/rwe.v10n2p74
Accepted: June 1, 2019

Online Published: July 8, 2019

URL: https://doi.org/10.5430/rwe.v10n2p74

\begin{abstract}
This study explores the underlying factors among SMEs that explain their intentions to use cloud accounting system in Malaysia. This study is motivated by the fact that SMEs are considered as significant economic players and an influential source of national and local economic growth. However, looking at high failure rate for Malaysian SMEs, more research should concern on supporting their business operation especially with regard to accounting or financial management. Based on the literature on this field as well as the concept in Unified Theory of Acceptance and Use of Technology (UTAUT) this study establishes a conceptual model that incorporate additional perceived security to the original four explanatory variables of UTAUT: performance expectancy, effort expectancy, social influence and facilitating condition. Hence, this paper proposes a conceptual framework of a modified UTAUT model with factors towards user intention to use cloud accounting system in Malaysia.
\end{abstract}

Keywords: cloud accounting, accounting information system, SME, intention, UTAUT

\section{Introduction}

The aim of this paper is to present current literature review on cloud accounting and its relation to small-and medium-sized enterprises (SMEs) in Malaysia with regard to its technology acceptance. At the end of this paper, a conceptual framework based on UTAUT model (Venkatesh, Morris, Davis, \& Davis, 2003) is revised and presented.

SMEs are considered as significant source of national, regional and local economic development in many countries (Wan Ismail \& Mokhtar, 2016). However, SMEs face common difficulties which threaten both their survival rate and performance. Past statistics indicated that the estimated failure rate for Malaysian SMEs was 60 per cent (Wan Ismail \& Mokhtar, 2016). Given the significance of SMEs for the stability and strength of the economy, understanding the factors of why SMEs fail and succeed is very crucial.

Many researchers (Lussier \& Halabi, 2010; Stokes \& Blackburn, 2002) agreed that accounting record is one of the factors that important in determining the success or failure of the SMEs. Despite the great benefits of maintaining accounting records, previous research however found that most of smaller firms do not keep them, hence fail to produce systematic accounting reports (Dyt \& Halabi, 2007; Kandhro \& Pathrannarakul 2013). The most efficient technique to report accounting data is by using accounting software or accounting information system (AIS). There are several researches investigating AIS adoption among SMEs (Ali, Rahman, \& Ismail, 2012; Breen, Sciulli, \& Calvert, 2003; Wan Ismail \& Mokhtar, 2016), however AIS adoption among SMEs with specific reference to cloud technology in Malaysia is almost non-existence.

\section{Literature Review}

The main purpose of each accounting system is denoted by gathering and storing of financial data and information related to economic events which give impact upon the organization, as well as the management, processing and disclosure of information to internal and external users (Christauskas and Miseviciene 2012; Ionescu et al. 2013; Hye, Lau \& Tourres 2014). There is a lot of benefit of AIS including the ability to simplify the accounting record as compared to manual accounting record but required great amount of investment, training and involve skilled accountants. It is the challenge that the entry, interpretation and auditing of accounting data is extremely dependent on 
understanding how accounting software works.

With reference to AIS generations by Phillips (2014) and other recent research, the up-to-date trend concerning the information system specifically in the field of accounting is the cloud computing technology, based on which the following terms derive namely cloud accounting, e-accounting, real-time accounting, online accounting, web-based accounting and cloud financials (Dimitriu \& Matei, 2015; B. S. Ionescu \& Prichici, 2013). Having stated this, this paper shifts the focus from traditional desktop accounting system to more advanced but easy and cost effective cloud accounting.

According to 2014 world quality report on software quality assurance, cloud-based software is progressively widely accepted and this trend will continue in near future. The report also shows that cloud migration is having momentum as $28 \%$ of applications are hosted in a cloud facility in 2014, and the portion of cloud-based systems is predicted to raise to $35 \%$ by 2017 (Capgemini, Sogeti, \& Hewlett, 2014; Idrees,et.al 2018). In terms of research field, there is a continuous increase in literature and practice of finance and accounting in the cloud (Brandas, Megan, \& Didraga, 2015). B. Ionescu, Ionescu, Tudoran, and Bendovschi (2013) discuss the differentiation between traditional desktop accounting software and cloud accounting and highlight the point that ownership issues. They stated unlike traditional desktop accounting software, cloud accounting software are not owned by the organization, but involves hardware and maintenance costs, unlimited number of users (Bosoteanu, 2016).

The major motivation for the worldwide adoption of cloud accounting is the economic benefit that cuts expenses using an external data centre where these applications are stored makes the purchase of additional hardware and software no longer necessary (Arsenie-Samoil, 2011; Gangwar, Date, \& Ramaswamy, 2015; Tarmidi, Rasid, Alrazi, \& Roni, 2014). By having cloud accounting, companies especially SMEs could save the cost with regard to maintenance cost as well as lack of additional cost (Belfo \& Trigo, 2013; Brandas et al., 2015; B. S. Ionescu \& Prichici, 2013). Moreover, this cloud technology could provide access to financial information without geographical limitations. This means that different type of stakeholders can have an access to accounting and financial data or applications with real time reporting from anywhere and anytime (Belfo \& Trigo, 2013; Ipole, Agba \& Okpa 2018).

The major concern with cloud accounting is the issue of security since accounting process involves storing sensitive and confidential data (Bosoteanu, 2016; Brandas et al., 2015; B. S. Ionescu \& Prichici, 2013). The stored data or information in AIS is crucial for SMEs such as payroll database and sales database. From legal perspective, the firm does not owns the infrastructure offered by the cloud service provider except for the data entered and thus, has less control over the processing systems as well as storage of the data (Brandas et al., 2015; Jacob, \& Mazuruse 2018). Consequently, storing crucial information in a facility outside of the firm has the consequence of raising the risk of loss of that data. It is reported that small companies have low interest to use cloud accounting compared to bigger companies due to security issues (B. S. Ionescu \& Prichici, 2013). Furthermore, the threat of security is also concerning the protection of customer financial information and susceptible to unauthorized access (Dimitriu \& Matei, 2014).

\section{Unified Theory of Acceptance and Use of Technology (UTAUT)}

Many theoretical models have been used to study the adoption of technological innovations among SMEs such as the Technology Acceptance Model (Grandon \& Pearson, 2004), TAM2 (Venkatesh, 2000), Diffusion on Innovation theory (Premkumar, 2003) and the Theory of Planned Behaviour (Harrison, Mykytyn Jr, \& Riemenschneider, 1997).

After reviewing those theories, UTAUT is regarded very comprehensive theory since it was developed through a review and consolidation of the constructs of eight models that earlier research (Venkatesh et al., 2003). As for basic concept, UTAUT has four key constructs which affects behavioral intention to use a technology. With reference to UTAUT, performance expectancy, effort expectancy, and social influence behavioral intention to use a technology, while behavioral intention and facilitating conditions have direct effect to technology use.

As for conceptual model of this paper, UTAUT model is used to examine the intention to use cloud accounting among SMEs in Malaysia where the element of perceived security is put into account as additional independent variable as in Figure 1. With regard to moderating variable, since the focus of the study is SMEs i.e. firm level, gender variable is dropped and replaced by organizational size. Voluntariness of use is also removed since there is no mandatory requirement imposed by Malaysian government or investors to use cloud accounting.

This construct is selected due to the nature of cloud computing or specifically cloud accounting involves highly confidential data and users need to maintain certain level of security if they agree to accept the system. This construct has been used in other revised technology adoption theory (Cheng, Lam, \& Yeung, 2006; Lallmahamood, 2007). Other similar construct such as perceived risk (Featherman \& Pavlou, 2003), perceived credibility and trust may fall under this category. Having reviewed previous literature, this paper define perceived security as the extent to which a user 
feel protected against security threats with regard information processed in the system when he or she accept the new technology (Cheng et al., 2006).

This study substitutes age with years of service as it is deemed more appropriate for situation of SMEs. The additional organizational size is considered as moderating variable in the model since it may reflect the capability or necessity of an entity to adopt new technology (Forés \& Camisón, 2016). It is also one of the most commonly studied causes of technology acceptance (Lee \& Xia, 2006).

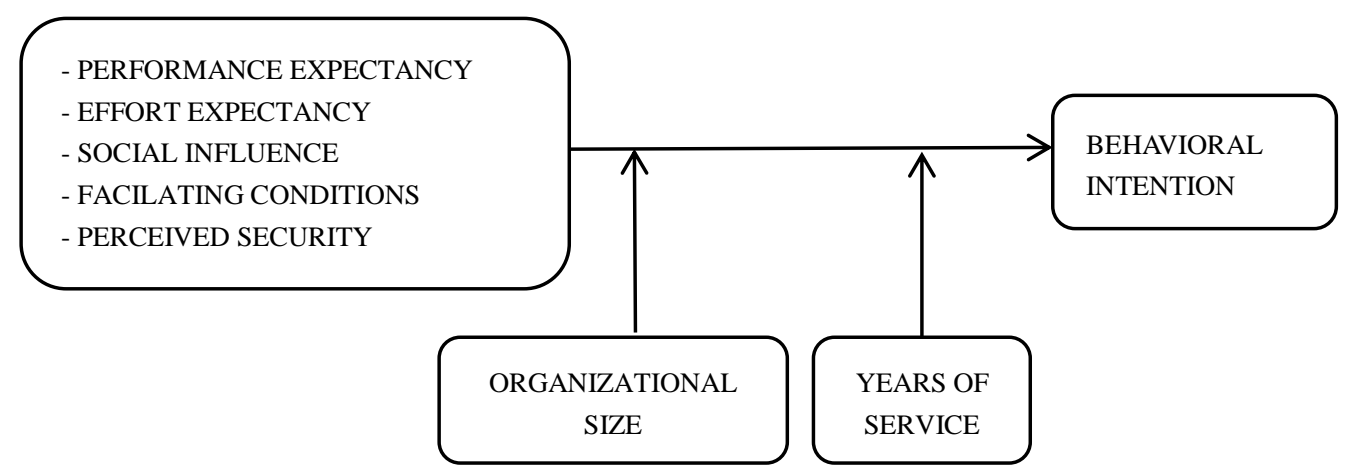

Figure 1

\section{Conclusion}

Cloud accounting in developing countries especially Malaysia has not been sufficiently researched. Considering this rarity of research in cloud accounting especially with the use of the UTAUT model, this paper investigates the model and proposed a modification specifically with regards to the SMEs' intention to use cloud accounting. From the in-depth literature review, this paper found that the major issue that may block SMEs from adopting cloud accounting despite the huge benefit offered by the cloud technology is the security of data. Thus, this paper incorporates perceive security to the original UTAUT adoption model. Since the paper only proposes a conceptual framework for examining user intention of cloud accounting among SMEs in Malaysia, thus, further research would focus on empirical validity and reliability of the conceptual framework.

\section{References}

Ali, A., Rahman, M. S. A., \& Ismail, W. (2012). Predicting Continuance Intention to Use Accounting Information Systems Among SMEs in Terengganu, Malaysia. International Journal of Economics and Management, 6(2), 295-320.

Arsenie-Samoil, M. D. (2011). Cloud Accounting. Ovidius University Annals, Economic Sciences Series, 2, $782-787$.

Belfo, F., \& Trigo, A. (2013). Accounting information systems: Tradition and future directions. Procedia Technology, 9, 536-546. https://doi.org/10.1016/j.protcy.2013.12.060

Bosoteanu, M. C. (2016). Cloud Accounting In Romania. A Literature Review. Risk in Contemporary Economy, 400-405.

Brandas, C., Megan, O., \& Didraga, O. (2015). Global perspectives on accounting information systems: mobile and cloud approach. Procedia Economics and Finance, 20, 88-93. https://doi.org/10.1016/S2212-5671(15)00051-9

Breen, J. P., Sciulli, N., \& Calvert, C. (2003). The use of computerised accounting systems in small business. 16th annual conference of small enterprise association of Australia and New Zealand.

Capgemini, Sogeti, \& Hewlett, P. (2014). World Quality Report 2014-15. Retrieved from https://www.capgemini.com/resources/world-quality-report-2014-15/

Cheng, T. C. E., Lam, D. Y. C., \& Yeung, A. C. L. (2006). Adoption of internet banking: an empirical study in Hong Kong. Decision Support Systems, 42(3), 1558-1572. https://doi.org/10.1016/j.dss.2006.01.002

Dimitriu, O., \& Matei, M. (2014). A new paradigm for accounting through cloud computing. Procedia Economics and Finance, 15, 840-846. https://doi.org/10.1016/S2212-5671(14)00541-3

Dimitriu, O., \& Matei, M. (2015). Accounting in the Cloud. Paper presented at the Proceedings of the MakeLearn and 
TIIM Joint International Conference 2015.

Dyt, R., \& Halabi, A. K. (2007). Empirical Evidence Examining the Accounting Information Systems and Accounting Reports of Small and Micro Business in Australia. Small Enterprise Research, 15(2), 1-9. https://doi.org/10.5172/ser.15.2.1

Featherman, M. S., \& Pavlou, P. A. (2003). Predicting e-services adoption: a perceived risk facets perspective. International journal of human-computer studies, $\quad 59(4), \quad 451-474$. https://doi.org/10.1016/S1071-5819(03)00111-3

Forés, B., \& Camisón, C. (2016). Does incremental and radical innovation performance depend on different types of knowledge accumulation capabilities and organizational size?. Journal of Business Research, 69(2), 831-848. https://doi.org/10.1016/j.jbusres.2015.07.006

Gangwar, H., Date, H., \& Ramaswamy, R. (2015). Understanding determinants of cloud computing adoption using an integrated TAM-TOE model. Journal of Enterprise Information Management, 28(1), 107-130. https://doi.org/10.1108/JEIM-08-2013-0065

Grandon, E. E., \& Pearson, J. M. (2004). Electronic commerce adoption: an empirical study of small and medium US businesses. Information \& Management, 42(1), 197-216. https://doi.org/10.1016/j.im.2003.12.010

Harrison, D. A., Mykytyn Jr, P. P., \& Riemenschneider, C. K. (1997). Executive decisions about adoption of information technology in small business: Theory and empirical tests. Information Systems Research, 8(2), 171-195. https://doi.org/10.1287/isre.8.2.171

Hye, Q. M. A., Lau, W. Y., \& Tourres, M. A. (2014). Does economic liberalization promote economic growth in Pakistan? An empirical analysis. Quality \& Quantity, 48(4), 2097-2119. https://doi.org/10.1007/s11135-013-9882-9

Idrees, R. Q., Shapiee, R., Ahamat, H., \& Hanwei, L. (2018). How Logistics Investment Arrangement is a Key Concern to China-Pakistan Economic Corridor (CPEC)? A Legal and Policy Analysis of CPEC Logistics Investment Model and Future Challenges for Pakistan. International Journal of Asian Social Science, 8(11), 1059-1067. https://doi.org/10.18488/journal.1.2018.811.1059.1067

Ionescu, B. S., \& Prichici, C. (2013, May). Potential Beneficiaries of Cloud Accounting technology: small or large Companies?. Manager Journal, 17(1), 282-292.

Ionescu, B., Ionescu, I., Tudoran, L., \& Bendovschi, A. (2013). Traditional accounting vs. Cloud accounting. Paper presented at the Proceedings of the 8th International Conference: Accounting and Management Information Systems, Bucharest, Romania.

Ipole, P. A., Agba, A. O., \& Okpa, J. T. (2018). Existing working conditions and labour unions agitations in cross river state civil service, Nigeria. Global Journal of Social Sciences Studies, 4(1), 39-51. https://doi.org/10.20448/807.4.1.39.51

Jacob, D., \& Mazuruse, P. (2018). Estimating Default Risk of Bank Loans in Zimbabwe Using the Mover-Stayer Model. Asian Journal of Economic Modelling, $220-234$. https://doi.org/10.18488/journal.8.2018.63.220.234

Kandhro, D., \& Pathrannarakul, P. (2013). The role of technology in enhancing transparency and accountability in public sector organizations of Pakistan. International Journal of Economics Business and Management Studies, 2(1), 20-24.

Lallmahamood, M. (2007). An Examination of Individual's Perceived Security and Privacy of the Internet in Malaysia and the Influence of this on their Intention to Use E-commerce: Using an Extension of the Technology Acceptance Model. Journal of Internet Banking and Commerce, 12(3), 1-1.

Lee, G., \& Xia, W. (2006). Organizational size and IT innovation adoption: A meta-analysis. Information \& Management, 43(8), 975-985. https://doi.org/10.1016/j.im.2006.09.003

Lussier, R. N., \& Halabi, C. E. (2010). A three-country comparison of the business success versus failure prediction model. Journal of Small Business Management, $48(3)$, 360-377. https://doi.org/10.1111/j.1540-627X.2010.00298.x

Phillips, B. A. (2014). How the cloud will change accounting forever. Pridobljeno, 12(12), 2014.

Premkumar, G. (2003). A meta-analysis of research on information technology implementation in small business. 
Journal of Organizational Computing and Electronic Commerce, 13(2), 91-121. https://doi.org/10.1207/S15327744JOCE1302_2

Stokes, D., \& Blackburn, R. (2002). Learning the hard way: the lessons of owner-managers who have closed their businesses. Journal of Small Business and Enterprise Development, 9(1), 17-27. https://doi.org/10.1108/14626000210419455

Tarmidi, M., Rasid, S. Z. A., Alrazi, B., \& Roni, R. A. (2014). Cloud computing awareness and adoption among accounting practitioners in malaysia. Procedia-Social and Behavioral Sciences, 164, 569-574. https://doi.org/10.1016/j.sbspro.2014.11.147

Venkatesh, V. (2000). Determinants of perceived ease of use: Integrating control, intrinsic motivation, and emotion into the technology acceptance model. Information Systems Research, 11(4), 342-365. https://doi.org/10.1287/isre.11.4.342.11872

Venkatesh, V., Morris, M. G., Davis, G. B., \& Davis, F. D. (2003). User acceptance of information technology: Toward a unified view. MIS quarterly, 425-478. https://doi.org/10.2307/30036540

Wan Ismail, W. N., \& Mokhtar, M. Z. (2016). Application of TOE Framework in Examining the Factors Influencing Pre- and Post-Adoption Of CAS in Malaysian SMEs. International Journal of Information Technology and Business Management, 49(1), 26-37. 